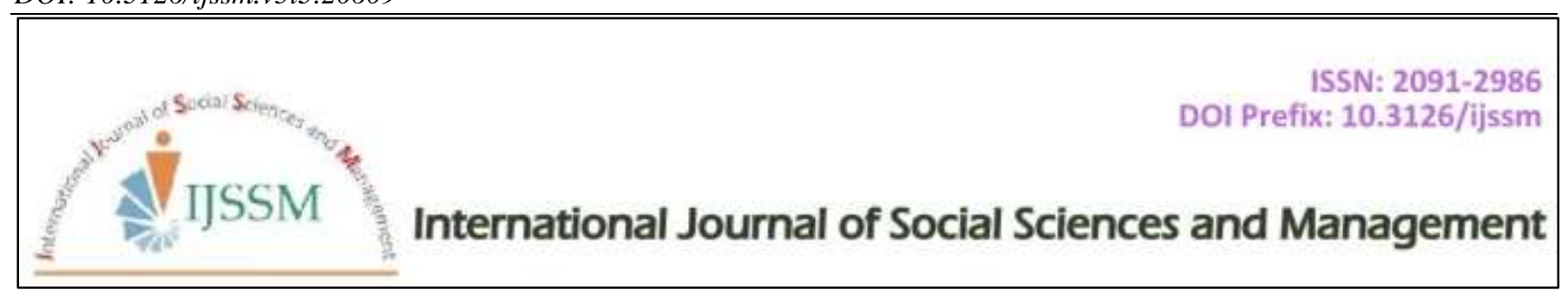

Research Article

\title{
Knowledge Attitude and Practice about Obesity and Its Complication in Rural Area of Lahore
}

\author{
Asma Anwar ${ }^{1 *}$, Muhammad Hussain ${ }^{1}$, Hajra Sarwar', Muhammad Afzal ${ }^{1}$, Syed Amir Gilani ${ }^{1}$ \\ ${ }^{1}$ Lahore School of Nursing, The University of Lahore, Pakistan
}

\section{Abstract}

Introduction: The population has not been investigated extensively about understanding and perception about obesity and its complications. The aim of the study was to investigate the understanding, recognition and practice between overall population in the selected areas of Lahore related to obesity and its complications. Methods: The descriptive study which involved 100 respondents. The respondents from Hussain Abad Lahore were conveniently approached and recruited. A pre-approved, questionnaire was used for data accumulation. SPSS version 20 was used both descriptive and inferential statistics. Results: From Out of the total 100 participants, 53\% were females and 47\% were males. Almost the half Participant $45 \%$ was in the age of 35years. Nearly $91 \%$ respondents don't have idea about normal body mass index of adults. While $89 \%$ participants don't know hormonal problems can lead the obesity. However 51\% participants know that obesity can lead the heart problems. . Just about $52 \%$ participants were agreeing that when the person consumes extra calories than the individual burns obesity can occurs. $44 \%$ participants were agreed that psychological factors can influence the eating habits and obesity more over 36\% are agreed that junk food takers are more susceptible to obesity. Only 3\% participant checks their Body Mass Index (BMI) level. $26 \%$ change their eating habits, physical activity in order to maintain their physique and $11 \%$ takes of junk food. Conclusion: The respondents were more careful that obesity happens when a man expends a bigger number of calories than a man devours it. However the respondents know about obesity and its entanglements to some degree, their preparation towards weight isn't general which ought to be investigated later on for better human administrations, and prosperity comes about.
\end{abstract}

Keywords: Rural area of Lahore; knowledge; attitude; practice; Obesity

\section{Introduction}

Obesity is the complex, multifactorial, and preventable disease, affect's in a form of overweight, affected over $33 \%$ of the total word's population. On the world perception it remain continue than in the 2030 as per an estimation 38\% of the world's aggregate grown-up populace will be overweight and $20 \%$ will be resolute (Rajiah and Mathew, 2013). Obesity is a well-established risk factor for the cardiovascular disease in the overall population. Cardiovascular disease is a primary cause of mortality and morbidity in the developed and developing countries. (Hruby and $\mathrm{Hu}, 2015$ ) Obese can be defined as individual ordinary weight typically a man has been thought to be obese if there is over than $20 \%$ over the ultimate weight. That perfect weight is take by the clarification of the individual's height, age, sex, and development. (Nair,

\section{Cite this article as:}

A. Anwar et al. (2018) Int. J. Soc. Sc. Manage. Vol. 5, Issue-3: 187-191. DOI: 10.3126/ijssm.v5i3.20609

$1 *$ Corresponding author

Asma Anwar,

Lahore School of Nursing, The University of Lahore, Pakistan

Email: anwarasma630@gmail.com

Peer reviewed under authority of IJSSM

(C) 2018 International Journal of Social Sciences and Management

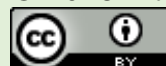

This is an open access article \& it is licensed under a Creative Commons Attribution 4.0 International License (https://creativecommons.org/licenses/by/4.0/)

Full text of this paper can be downloaded online at www.ijssm.org/ \&http://nepjol.info/index.php/IJSSM/issue/archive 
Hanumantappa, Hiremath, Siraj, and Raghunath, 2014). Obesity is described by the National Institutes of Health (the $\mathrm{NIH}$ ) as a BMI (Body Mass Index) of 30 and the sky is the limit from there. (A BMI of 30 is around 30 pounds overweight.) The BMI, a key record for relating body weight to stature, is a man's weight in kilograms $(\mathrm{kg})$ partitioned by their tallness in meters (m) squared Bleich, Bennett, Gudzune, and Cooper, 2012). The aggregate frequency of obesity worldwide has empowered the World Health Organization (WHO) to assign as obesity amongst the most huge overall wellbeing perils. The wellspring of this epidemic is grim way of life high-vitality and high-fat eating routine style, physical apathy and smoking (Hruby and $\mathrm{Hu}, 2015)$.

\section{Research Question}

What is the knowledge attitude and believe of community resident related to the obesity and its complication?

\section{Aims of the Study}

This study estimated the knowledge, attitude and practice of resident's people related obesity and its complication.

\section{Significance of the Study}

Many studies have been conducted on obesity and its complication related knowledge, attitude and practices but there are limited studies which have done in the community. The study will help to assess the resident's knowledge, attitude and practice that the residents have good knowledge, attitude and practice to maintain good health. Moreover, study will assess the gap that either resident have the knowledge but not use in practices or either residents have not knowledge that's why resident's practices are poor. This gap will help the organizations in making polices to improve the residents practices as well as to enhance the knowledge by conducting seminar or teaching session.

\section{Literature Review}

As indicated by an investigation of USA, the obesity will be $85 \%$ till 2030. While the advance's of creating obesity in most created nations appear like leveled, however in huge numbers of these nations keeps on expanding, including among youngsters. Also, weight pervasiveness in creating nations is proceeds with increment toward US levels (Schauer et al., 2012).

Pakistan right now positions sixth among the most crowded nations of the world, and its development rate are most elevated in Asia i.e. 2.8\%. Late information from both the National Nutrition review (NNS-2011) and Pakistan Demographic and Health Survey (PDHS2012-13) demonstrated a persevering high predominance of undernourishment and pallor among ladies existing together with huge extent of overweight and large ladies. A little scale ponder directed in ladies more than 25 years old living in a low salary group uncovered a higher commonness of $42 \%$ overweight and $8 \%$ weight among ladies with abdominal area corpulence conveying higher danger of cardiovascular ailment (CVD). Pakistan's National Health Survey (NHS 1990-94) found that the pervasiveness of heftiness for grown-ups between age 25 to 64 from low, center and high SES was $9 \%, 15 \%$ and $27 \%$ for rustic zones and $21 \%, 27 \%$ and $42 \%$ for urban zones separately (Mehboob, Safdar, and Zaheer, 2016).

\section{Conceptual Framework}

Fig. 1 shows the conceptual framework of this study.

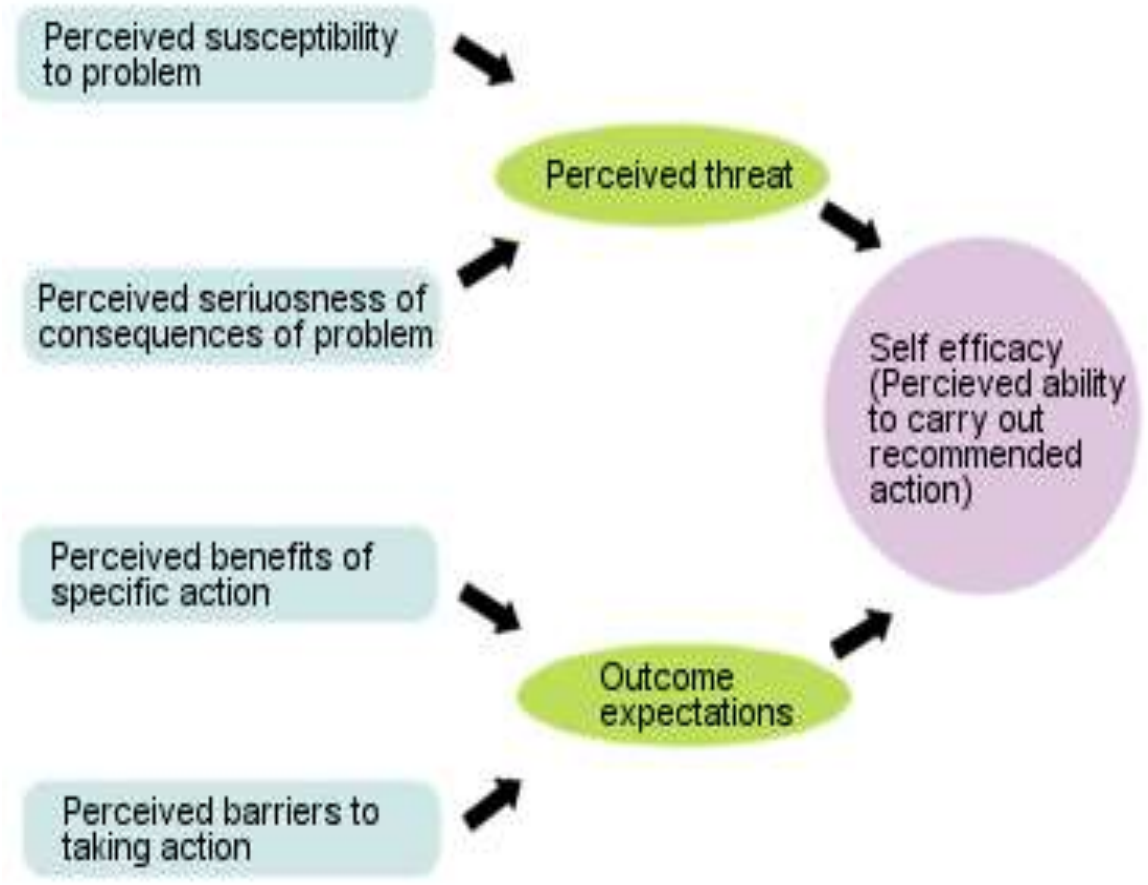

Fig. 1: Conceptual framework 
The Heath Belief Model will create to clarify the wellbeing conduct and furthermore apply to disease or disorder behavior. As indicated by this model the people are participate in wellbeing practices, for example, safe practices of weight and its complication, an individual needs to see himself as defenseless or helpless to a wellbeing danger. That health danger must be seen as having serious results. The defensive activity that is accessible must be seen as exceeding the apparent cost of the activity. However notwithstanding when individual, see that they could receive a specific game-plan, some trigger may be required to push them vigorously.

\section{Methods}

\section{Setting}

The research was conducted in Hussain Abad community.

\section{Research Design}

The study was analytical cross sectional study design.

\section{Population}

The target populations were male and female of Hussain Abad community Lahore

\section{Sampling}

Respondents' selection was 100 .

\section{Research Instrument}

A questionnaire was designed for this study to gather data to answer the research questions.

\section{Data Gathering Procedure}

A Close ended questioner was adopted from base line article.

\section{Methods Used to Analyze Data}

Data entry was completed by the primary investigator at SPSS.

\section{Study Timeline}

The data was collected from Sep, 2017 to Jan, 2018.

\section{Ethical Consideration}

The study will be approved and controlled by The Institutional Review Board (IRB) of University of Lahore, the stake holder of Hussain Abad community and The individual consent will also be signed before getting information.

\section{Results}

\section{Demographic Characteristics}

Out of the 100 respondents, $53 \%$ of the respondents were females while $47 \%$ comprised of men. Almost $50 \%$ of the respondents $(45 \%)$ were in the age gathering of over 35 . The greater part of the respondents $(54.78 \%)$ was accounted for to have their own particular business. Full statistic attributes of respondents are explained in Table 1.

Table 1: Demographics of Participants (Age, Gender, Qualification and Monthly Income)

\begin{tabular}{|c|c|c|c|}
\hline Demographics & Options & Frequency & Percentage \\
\hline & Female & 53 & 53.0 \\
\hline \multirow[t]{2}{*}{ Gender of participant } & Male & 47 & 47.0 \\
\hline & $<18$ yrs & 7 & 7.0 \\
\hline \multirow[t]{4}{*}{ Age of participant } & $18-25 y r s$ & 23 & 23.0 \\
\hline & $26-35 y r s$ & 38 & 38.0 \\
\hline & $>35 y r s$ & 32 & 32.0 \\
\hline & Illiterate & 23 & 23.0 \\
\hline \multirow[t]{4}{*}{ Qualification of participant } & Primary & 30 & 30.0 \\
\hline & Middle & 31 & 31.0 \\
\hline & Matric & 6 & 6.0 \\
\hline & Above & 10 & 10.0 \\
\hline \multirow[t]{4}{*}{ Monthly income of participant } & $<15000-16000$ & 5 & 5.0 \\
\hline & $25000-26000$ & 34 & 34.0 \\
\hline & $35000-36000$ & 44 & 44.0 \\
\hline & 45000 & 17 & 17.0 \\
\hline
\end{tabular}




\section{Knowledge towards Obesity and Its Complications}

Just about (91\%) respondents addressed that they don't have the foggiest idea about the ordinary weight record of a grown-up. While $89 \%$ addressed that they don't know hormone issues can prompt heftiness. However 51\% respondents do realize that obesity can prompt heart issues. These all are outlined in Table 2.

\section{Attitude towards Obesity and its Complications}

Right around 52\% members are concurring that obesity happens when a man expends a greater number of calories than a man consumes it. $44 \%$ members are concur that mental factors likewise impact dietary patterns and heftiness and $36 \%$ are concur that garbage sustenance eaters are more inclined to weight. These all are explained in Table 2.

\section{Practice towards Obesity and its Complications}

Just 3\% member checks their Body Mass Index (BMI) level. $26 \%$ alter their dietary patterns, physical movement so as to keep up your constitution. Furthermore, $11 \%$ takes of garbage sustenance. These all are explained in Table 2.

Table 2: Knowledge, Attitude and Practice regarding Obesity and its Complication.

\begin{tabular}{|c|c|c|c|}
\hline Questions & Options & Frequency & Percentage \\
\hline \multirow{2}{*}{$\begin{array}{l}\text { 1. Do you know the normal body mass index of an } \\
\text { adult? }\end{array}$} & Yes & 9 & 9.0 \\
\hline & NO & 91 & 91.0 \\
\hline \multirow[t]{2}{*}{$\begin{array}{l}\text { 2. Do you know that hormone problems like } \\
\text { hypothyroidism can lead to obesity }\end{array}$} & Yes & 11 & 11.0 \\
\hline & NO & 89 & 89.0 \\
\hline \multirow{2}{*}{$\begin{array}{l}\text { 3. Do you know that obesity can lead to heart } \\
\text { problems? }\end{array}$} & Yes & 49 & 49.0 \\
\hline & NO & 51 & 51.0 \\
\hline \multirow{4}{*}{$\begin{array}{l}\text { 4. Do you agree that obesity occurs when a person } \\
\text { consumes more calories than a person burns it? }\end{array}$} & Strongly Agree & 28 & 28.0 \\
\hline & Agree & 52 & 52.0 \\
\hline & Disagree & 10 & 10.0 \\
\hline & Strongly Disagree & 10 & 10.0 \\
\hline \multirow{4}{*}{$\begin{array}{l}\text { 5. Do you agree that psychological factors also } \\
\text { influence eating habits and obesity? }\end{array}$} & Strongly Agree & 41 & 41.0 \\
\hline & Agree & 44 & 44.0 \\
\hline & Disagree & 8 & 8.0 \\
\hline & Strongly Disagree & 7 & 7.0 \\
\hline \multirow{4}{*}{$\begin{array}{l}\text { 6. Do you agree that junk food eaters are more } \\
\text { prone to obesity? }\end{array}$} & Strongly Agree & 41 & 41.0 \\
\hline & Agree & 36 & 36.0 \\
\hline & Disagree & 7 & 7.0 \\
\hline & Strongly Disagree & 16 & 16.0 \\
\hline \multirow{4}{*}{$\begin{array}{l}\text { 7. How often do you check your Body Mass Index } \\
\text { (BMI) level? }\end{array}$} & Every time & 3 & 3.0 \\
\hline & Most of the time & 15 & 15.0 \\
\hline & Some time & 37 & 37.0 \\
\hline & Very rare & 45 & 45.0 \\
\hline \multirow{4}{*}{$\begin{array}{l}\text { 8. Do you modify eating habits, physical activity in } \\
\text { order to maintain your physique? }\end{array}$} & Every time & 0 & 0 \\
\hline & Most of the time & 26 & 26.0 \\
\hline & Some time & 43 & 43.0 \\
\hline & Very rare & 31 & 31.0 \\
\hline \multirow{4}{*}{$\begin{array}{l}\text { 9. How much amount of junk food you consume in } \\
\text { a day approximately? }\end{array}$} & Every time & 11 & 11.0 \\
\hline & Most of the time & 23 & 23.0 \\
\hline & Some time & 50 & 50.0 \\
\hline & Very rare & 16 & 16.0 \\
\hline
\end{tabular}




\section{Discussion}

The idea of knowledge related to obesity and complication in the people living in rural area, their attitudes and practice toward it was investigated. Results show that majority of the participants seemed to have little information on complications of obesity. Their attitude related to the obesity and its complication the participants were not frequently checking their body mass index. The results revealed that many participants do not have idea that hormonal problems can cause obesity. Mostly participants of study know that obesity can cause to heart related problems. While large number of participants know about adult's normal body mass index, it is not determined that the participants have the correct idea. That's why it was a closed-ended question and therefore the level of their knowledge related the normal value may not be correct from the outcomes, it's marked that half of the participants strongly agree about junk food takers are more disposed to obesity. Also mostly participants disagree that mental factors also affect eating styles and obesity which is supposedly not correct. Although many of the participants supposed that junk food takers are more disposed to obesity, only a small proportion of participants eat junk food once a while mostly they consume.

\section{Limitations}

Participants in this research were not from general population and another limitation is small sample size.

\section{Conclusion}

The respondents were more mindful that obesity happens when a man expends a bigger number of calories than a man consumes it. Despite the fact that the respondents know about obesity and related complication to some degree, their training towards weight isn't broad which ought to be investigated later on for better social insurance, and wellbeing results.

\section{References}

Ahmad S, Zhao W, Resnström F, Rasheed A, Samuel M, Zaidi M and Ishaq M (2015) Physical activity, smoking, and genetic predisposition to obesity in people from Pakistan: the PROMIS study. BMC medical genetics 16(1): 114.
Bleich SN, Bennett WL, Gudzune KA and Cooper, L A (2012) Impact of physician BMI on obesity care and beliefs. Obesity, 20(5), 999-1005.

Dictionaries O (2006) Oxford English Dictionary 2012.

Dietz WH, Baur LA, Hall K, Puhl RM, Taveras EM, Uauy R and Kopelman P (2015) Management of obesity: improvement of health-care training and systems for prevention and care. The Lancet 385(9986): 2521-2533.

Eliopoulos C (2013) Gerontological nursing: Lippincott Williams and Wilkins

Hasnain S (2015) Effect of the common fat mass and obesity associated gene variants on obesity in Pakistani population: a case-control study. BioMed research international 2015.

Hruby A and Hu FB (2015) The epidemiology of obesity: a big picture. Pharmacoeconomics 33(7): 673-689.

Mehboob B, Safdar NF, and Zaheer S (2016) Socio-economic, environmental and demographic determinants of rise in obesity among Pakistani women: A Systematic Review. JPMA. The Journal of the Pakistan Medical Association, 66(9): 1165-1172.

Micklesfield LK, Lambert EV, Hume DJ, Chantler S, Pienaar PR, Dickie K and Puoane T (2013) Socio-cultural, environmental and behavioural determinants of obesity in black South African women: Review articles. Cardiovascular journal of Africa 24(9): 369-375.

Nair SS, Hanumantappa R, Hiremath SG, Siraj MA and Raghunath P (2014) Knowledge, attitude, and practice of hand hygiene among medical and nursing students at a tertiary health care centre in Raichur, India. ISRN preventive medicine, 2014.

Popkin BM, Adair LS and Ng SW (2012) Global nutrition transition and the pandemic of obesity in developing countries. Nutrition reviews 70(1): 3-21.

Rajiah K and Mathew EM (2013) A cross sectional study among Malaysian population in selected states of Malaysia towards obesity and its complications.

Shub M and Sullivan D (1974) A remark on the Lefschetz fixed point formula for differentiable maps. Topology 13(2): 189-191. 